\title{
Purification of Mengovirus and Identification of an A-rich Segment in its Ribonucleic Acid
}

\author{
(Accepted 7 September 1972 )
}

Poly (A) segments form a part of mammalian mRNA (Darnell, et al. I97I ; Edmonds, Vaughan \& Nakazato, I97I; Mendecki, Lee \& Brawerman, 1972), vaccinia virus mRNA (Kates, 1970) and the RNA of a number of RNA viruses (Armstrong et al. 1972; Gillespie, Marshall \& Gallo, 1972; Johnston \& Bose, 1972; Lai \& Duesberg, 1972). The potential significance of the poly (A) segment in mRNA function is unknown, but it is of interest that the genomes of RNA tumour viruses contain a much greater proportion of poly $(A)$ than the RNAs of other viruses and that poly (A) segments have not been detected in virus RNAs that do not function directly as mRNA, such as the RNAs of influenza virus, Newcastle disease virus and vesicular stomatitis virus (Gillespie et al. 1972; Lai \& Duesberg, 1972). It has been reported that the poly (A) segment of poliovirus RNA represents $0.75 \%$ (Armstrong et al. 1972) or $0.25 \%$ (Gillespie et al. 1972) of the total nucleotide content of the virus genome. Our data show that mengovirus RNA contains an A-rich segment of approximately I6 nucleotides, which represents only about $0.19 \%$ of the total genome.

Mengovirus and mengovirus RNA were prepared as follows. Cultured Novikoff rat heptoma cells (subline NISI-67) were infected with Io to $30 \mathrm{p.f.u}$./cell of mengovirus as described previously (Plagemann, I968), and suspended to $4 \times 10^{6} \mathrm{cells} / \mathrm{ml}$ in basal medium 42 (BM 42) (Plagemann \& Swim, I966). The suspensions were supplemented with $2 \mu \mathrm{g}$ of actinomycin $\mathrm{D} / \mathrm{ml}$ at $30 \mathrm{~min}$ after infection and with $0.5 \mu \mathrm{M}-\left[{ }^{3} \mathrm{H}-8\right]$-adenosine $(2 \mathrm{mCi} / \mu-\mathrm{mol})$ or with $0.5 \mu \mathrm{M}-\left[{ }^{3} \mathrm{H}-5\right]$-uridine $(2 \mathrm{mCi} / \mu$-mol; Schwarz/Mann) at $\mathrm{I} \mathrm{h}$ after infection. At $7 \mathrm{~h}$ after infection the suspensions were frozen and thawed and then clarified of cell debris by centrifuging at $1000 \mathrm{~g}$ for $10 \mathrm{~min}$ at $4{ }^{\circ} \mathrm{C}$. Mengovirus was further purified from the supernatant fluid by a procedure similar to that recently described for EMC virus (Kerr \& Martin, 1972). One litre of clarified cell lysate was supplemented with $6 \%(\mathrm{w} / \mathrm{w})$ of polyethylene glycol (6000, Baker Chemical Co.) and $0.0 \mathrm{I} \%(\mathrm{v} / \mathrm{v})$ of mercapto-ethanol and stirred with a magnetic stirrer at $0{ }^{\circ} \mathrm{C}$ for $\mathrm{I} h$. The precipitate was collected by centrifuging at $5000 \mathrm{~g}$ for $20 \mathrm{~min}$ and suspended in $10 \mathrm{ml}$ of a solution composed to $100 \mathrm{~mm}$-tris- $\mathrm{HCl}(\mathrm{pH} \mathrm{8.2)}$ and $20 \mathrm{~mm}-$ EDTA (B 13). The suspension was treated with a $20-\mathrm{Kc}$ MSE sonic oscillator (I cm probe) at $0^{\circ} \mathrm{C}$ for $30 \mathrm{~s}$ and $5 \mathrm{ml}$ samples were layered over $33 \mathrm{ml}$ linear 0.5 to $\mathrm{I} \cdot 6 \mathrm{M}$ gradients of sucrose in B I3. The gradients were centrifuged in a SW 27 rotor in a L-2 Beckman ultracentrifuge at $24000 \mathrm{rev} / \mathrm{min}$ at $4{ }^{\circ} \mathrm{C}$ for $6 \mathrm{~h}$. One $\mathrm{ml}$ fractions were collected from the gradients by means of an ISCO gradient fractionator (Model 183) which was attached to a continuously recording spectrophometer and a fraction collector. Samples of the fractions were analysed for HA activity (Plagemann \& Swim, I966) and radioactivity in acid-insoluble material (Plagemann, 1968). The fractions which contained the virus were pooled from one or more gradients, diluted eightfold with $\mathrm{B} \mathrm{I} 3$ and concentrated by ultrafiltration on a Diaflo membrane (XM 300, Amicon Corp., Lexington, Mass.) to approximately $10 \mathrm{ml}$. The virus suspension was again centrifuged through a sucrose density gradient and subsequently concentrated by ultrafiltration as previously described. The results from a typical purification of $\left[{ }^{3} \mathrm{H}\right]$-uridine-labelled virus are summarized in Table I. About $50 \%$ of the original virus was recovered in the final preparation. The amount of protein in $0.5 \mathrm{ml}$ 
Table I. Purification of mengovirus

\begin{tabular}{|c|c|c|c|c|c|c|}
\hline \multirow[b]{2}{*}{ Purification step* } & \multicolumn{4}{|c|}{ Total } & \multirow[b]{2}{*}{$\begin{array}{l}\text { HA units/ } \\
\mu \mathrm{g} \text { protein }\end{array}$} & \multirow{2}{*}{$\begin{array}{c}\text { Virus } \\
\text { recovery } \\
\%\end{array}$} \\
\hline & $\begin{array}{l}\text { Volume } \\
(\mathrm{ml})\end{array}$ & $\underset{\text { (units) }}{\mathrm{HA}}$ & $\begin{array}{c}{\left[{ }^{3} \mathrm{H}\right]} \\
\text { (ct/min) }\end{array}$ & $\begin{array}{l}\text { Protein } \\
\quad(\mu \mathrm{g})\end{array}$ & & \\
\hline d cell lysate & 1000 & $13 \times 10^{5}$ & $18 \times 10^{6}$ & 245000 & $5 \cdot 2$ & 100 \\
\hline yline glycol precipitate & 10 & $10 \times 10^{5}$ & $12 \times 10^{6}$ & 9100 & 113 & 77 \\
\hline $\begin{array}{l}\text { sedimentation and } \\
\text { iltration }\end{array}$ & 10 & $8 \cdot 2 \times 10^{5}$ & $\mathrm{II} \times \mathrm{IO}^{6}$ & 500 & 1640 & 63 \\
\hline dimentation and & 10 & $6.4 \times 10^{\overline{5}}$ & $9 \times 10^{6}$ & $<200$ & $<3200$ & 49 \\
\hline
\end{tabular}

* The virus was purified as described in the text.

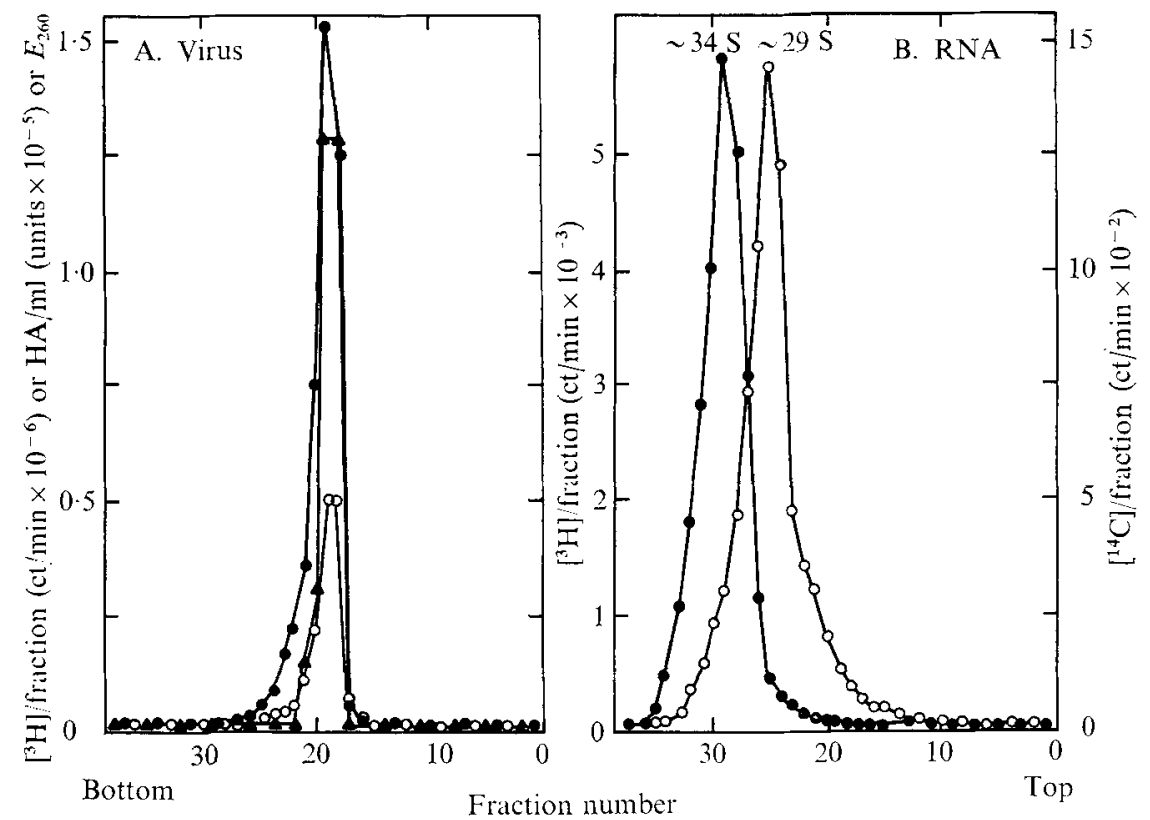

Fig. I. Sucrose density gradient sedimentation of purified mengovirus (A) and mengovirus RNA (B). (A) $\left[{ }^{3} \mathrm{H}\right]$-uridine-labelled mengovirus was purified as described in the text. A second sucrose density gradient was monitored for $E_{260}(O-O)$ and $0.1 \mathrm{ml}$ samples of each fraction from the gradient were analysed for $\mathrm{HA}$ activity $(\mathbf{\Lambda}-\mathbf{\Delta})$ and radioactivity in acid-insoluble material $(\mathbf{C}-\mathbf{C})$. (B) A sample of RNA extracted from $\left[{ }^{3} \mathrm{H}\right]$-uridine-labelled virus was mixed with a sample of purified $\left[{ }^{14} \mathrm{C}\right]$-labelled $29 \mathrm{~S}$ rRNA and centrifuged through a linear 0.15 to $0.9 \mathrm{M}$ gradient of sucrose in B 6 (Plagemann, 1970) in a SW 27 rotor, at $24000 \mathrm{rev} / \mathrm{min}, 20^{\circ} \mathrm{C}$ for $12 \mathrm{~h}$. Fractions from the gradient were analysed for $\left[{ }^{14} \mathrm{C}\right](\mathrm{O}-\mathrm{O})$ and $\left[{ }^{3} \mathrm{H}\right](-)$ in acid-insoluble material.

of the virus suspension $\left(3 \times \mathrm{IO}^{4} \mathrm{HA}\right.$ units) was below that detectable by the method of Lowry et al. (195I). The specific activity was therefore at least $3200 \mathrm{HA}$ units $/ \mu \mathrm{g}$ protein. The radioactivity, extinction and HA profiles from the second sucrose density gradient sedimentation (Fig. I A) also indicate that the virus was free of contaminating material.

The virus RNA was isolated from purified virus by extraction with sodium dodecylsulphate and phenol as described previously (Plagemann \& Swim, I968). As indicated in Fig. I B, the RNA sedimented as a homogeneous fraction. A sedimentation coefficient of about $34 \mathrm{~S}$ was estimated for the virus RNA by the method of Martin \& Ames (I96I) using cosedimented $\left[{ }^{14} \mathrm{C}\right]$-labelled purified $29 \mathrm{~S}$ rRNA from $\mathrm{N}_{I} \mathrm{~S}_{\mathrm{I}}-67$ cells (Plagemann, 1970) as a 


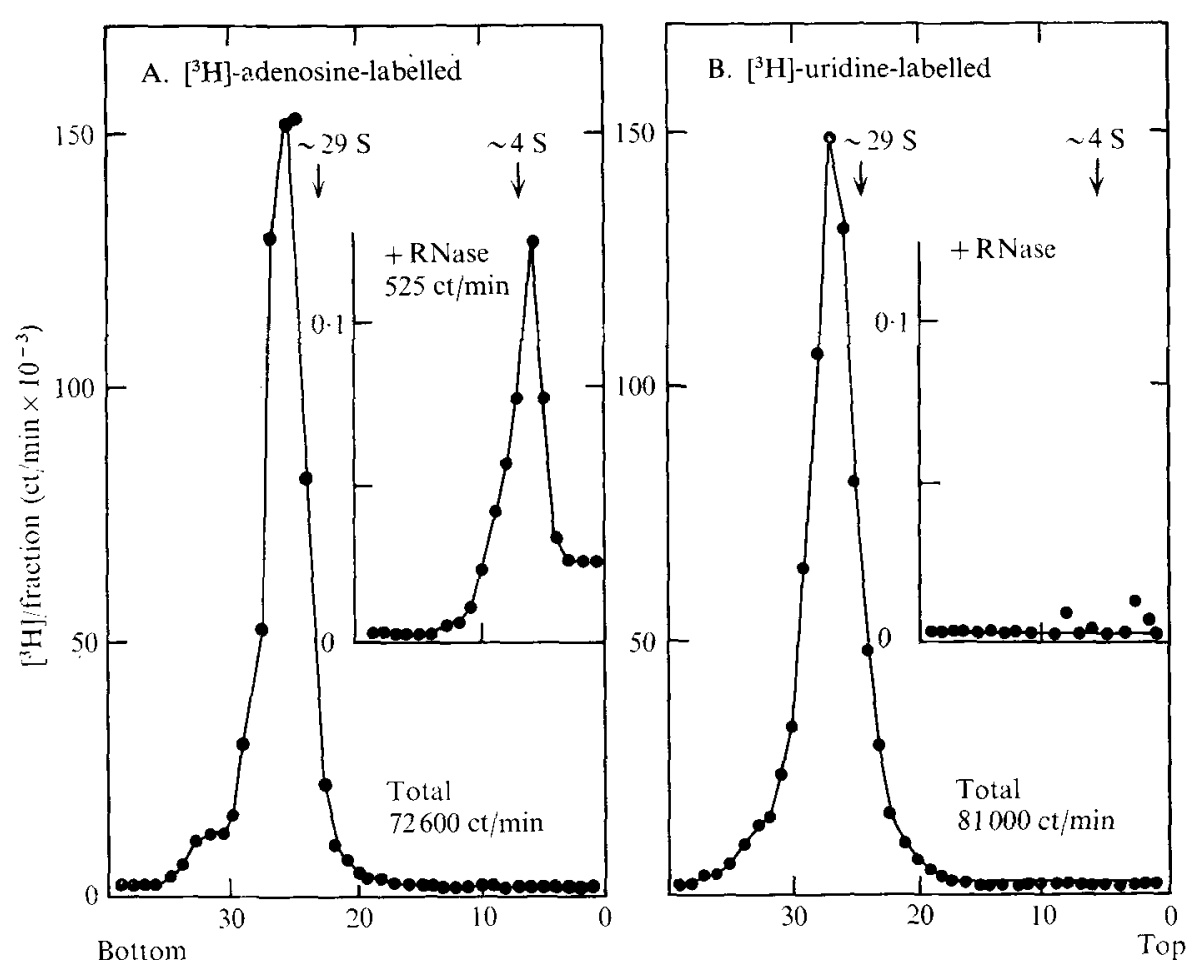

Fraction number

Fig. 2. Suclose density gradient sedimentation of $\left[{ }^{3} \mathrm{H}\right]$-adenosine $(\mathrm{A})$ and $\left[{ }^{3} \mathrm{H}\right]$-uridine-labelled (B) mengovirus RNA without and with prior treatment with RNase. Samples of $3 \mathrm{ml}$ of virus RNA in $\times 2$ SSC were supplemented with $40 \mu \mathrm{g}$ RNase A and $20 \mu \mathrm{g}$ RNase Tl per $\mathrm{ml}$ and incubated at $27^{\circ} \mathrm{C}$ for $60 \mathrm{~min}$. These samples and samples of untreated RNA in $\times 2$ SSC were then analysed by sucrose density gradient centrifugation as described in the legend to Fig. I B, except that the gradients were centrifuged for I I rather than $12 \mathrm{~h}$.

marker. Based on the Spirin equation (Spirin, 1963), the mol. wt. of mengovirus RNA was estimated as $2.8 \times 10^{6}$. Samples of virus RNA extracted from $\left[{ }^{3} \mathrm{H}\right]$-adenosine or $\left[{ }^{3} \mathrm{H}\right]$ uridine-labelled virus were suspended in a solution composed of $0.3 \mathrm{M}-\mathrm{NaCl}$ and $0.03 \mathrm{M}-$ sodium citrate ( $\times 2 \mathrm{SSC}$ ) and incubated with $40 \mu \mathrm{g}$ of RNase A (Sigma Chemical Co.) and $20 \mu \mathrm{g}$ of RNase T I (Worthington Biochemical Corp.) per $\mathrm{ml}$ at $27{ }^{\circ} \mathrm{C}$ for $60 \mathrm{~min}$. As indicated by the data in Fig. 2 B, uridine-labelled virus RNA was completely degraded to acidsoluble material, whereas approximately $0.75 \%$ of the adenosine-labelled virus RNA was not solubilized and was recovered in a low-molecular weight fraction (Fig. 2A). Similar results

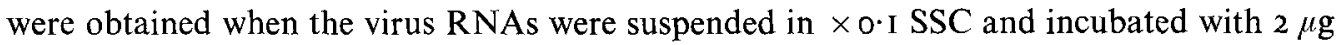
each of RNase A and T I at $27^{\circ} \mathrm{C}$ for $30 \mathrm{~min}$ (not shown). Samples of RNA were also hydrolysed in $\mathrm{NaOH}$ and the nucleotides were separated by high-voltage electrophoresis (Plagemann, 1972). The results showed that $100 \%$ of the adenosine label in RNA was associated with AMP, and that $86 \%$ of the uridine label was associated with UMP and I4\% with CMP.

Based on a mol. wt. of $2.8 \times 10^{6}$ for mengovirus RNA, an average mol. wt. of the monophosphonucleotides of $35^{\circ}$ and an overall base composition of the RNA of approximately $25 \%$ of each of the four bases (unpublished data), we estimated that mengovirus RNA is composed of approximately 8000 monophosphonucleotides, of which 2000 would be AMP. 


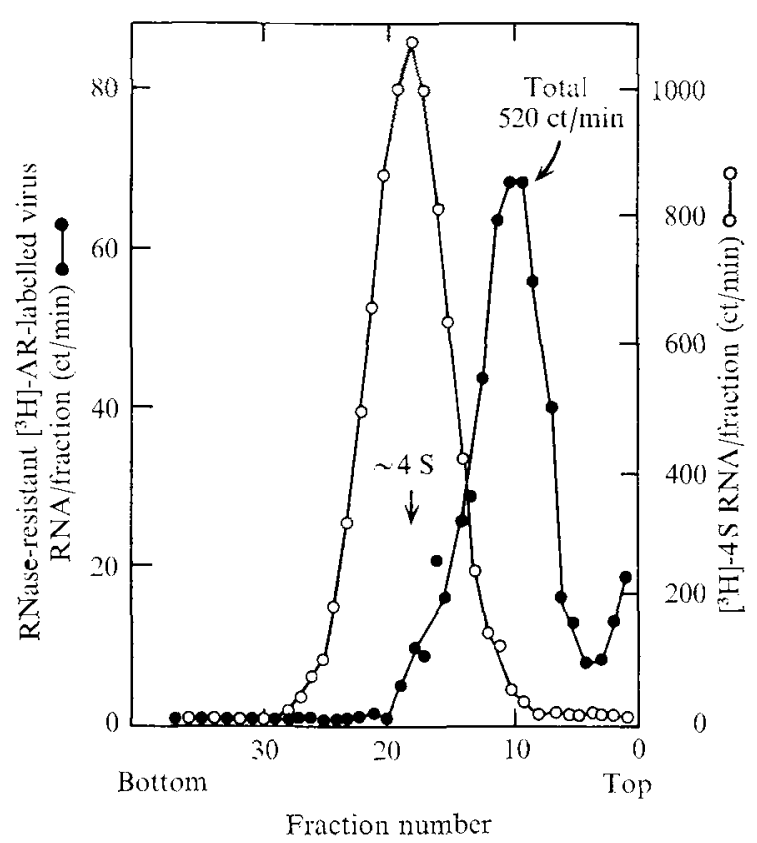

Fig. 3. Sedimentation analysis of 4 S tRNA and of poly (A) released from mengovirus RNA by RNase treatment. A sample of $\left[{ }^{3} \mathrm{H}\right]$-adenosine-labelled mengovirus RNA ( $\left.72000 \mathrm{ct} / \mathrm{min}\right)$ was incubated in $\times 2$ SSC containing $40 \mu \mathrm{g}$ of each RNase A and Tl per ml at $27{ }^{\circ} \mathrm{C}$ for $60 \mathrm{~min}$ and then analysed by sucrose density gradient centrifugation as described in the legend to Fig. I B, except that the gradient was centrifuged for 58 rather than $12 \mathrm{~h}(-)$ ). A sample of [ $\left.{ }^{3} \mathrm{H}\right]$-labelled $4 \mathrm{~S}$ tRNA in $\times 2$ SSC was co-sedimented in an accompanying gradient $(\mathrm{O}-\mathrm{O})$. The graph is a composite of the radioactivity profiles of the two gradients.

Since $0.75 \%$ of the AMP in the virus RNA is resistant to degradation by RNase A and T I we estimate that mengovirus RNA contains an A-rich segment containing approximately I5 AMPs. This calculation is based on the assumption that every virus RNA molecule contains a single A-rich segment of equal length. This conclusion is supported by a more direct analysis of the mol. wt. of the A-rich segment released from virus RNA by the RNase treatment. The A-rich segment sedimented only about half as rapidly in a sucrose density gradient as $4 \mathrm{~S}$ tRNA (Fig. 3). According to the method of Martin \& Ames (I96I), we estimated a sedimentation coefficient of $\mathrm{I} \cdot 9 \mathrm{~S}$ for this material which is equivalent to a mol. wt. of approximately 6000 as estimated by the Spirin formula and a content of approximately 17 nucleotides. Thus both methods of calculating the size of the A-rich segment of mengovirus RNA yielded similar results. The results therefore are consistent with the conclusion that each mengovirus RNA molecule contains a single segment composed of 15 to I 7 AMPs. The data reported by Gillespie et al. (1972) suggest that poliovirus RNA contains a poly (A) segment of similar length whereas Armstrong et al. (1972) estimated from their data that the poly (A) segment of poliovirus RNA consists of 50 to 70 AMPs. Present work is directed towards determining the location of the poly (A) segment in mengovirus virus RNA and in mengovirus double-stranded RNA. 
This work was supported by Public Health Service research grant 07250 . We thank John Erbe for excellent technical assistance and Merk \& Co. for a gift of actinomycin D.

Department of Microbiology

R. L. Miller

Medical School

P. G. W. Plagemann

University of Minnesota

Minneapolis, Minn. 55455

U.S.A.

\section{REFERENCES}

armstrong, J. A., edmonds, M., Nakazato, H., Philips, B. A. \& Vaughan, M. H. (I972). Polyadenylic acid sequences in the virion RNA of poliovirus and eastern equine encephalitis virus. Science, New York $\mathbf{1 7 6}$, 526-528.

DARNell, J. E., PHILIPSON, L., WAll, R. \& ADESNiK, M. (I97 I). Polyadenylic acid sequences: role in conversion of nuclear RNA into messenger RNA. Science, New York 174, 507-510.

edmonds, M., Vaughan, M. H. \& Nakazato, H. (197I). Polyadenylic acid sequences in the heterogeneous nuclear RNA and rapidly-labeled polyribosomal RNA of HeLa cells: possible evidence for a precursor relationship. Proceedings of the National Academy of Sciences of the United States of America 68, 13361340 .

GILlESPIE, D., MARSHALL, S. \& GALLO, R. C. (1972). RNA of RNA tumor viruses contains poly (A). Nature New Biology 236, 227-23I.

JOHNSTON, R. E. \& BOSE, H. R. (1972). An adenylate-rich segment in the virion RNA of Sindbis virus. Biochemical Biophysical Research Communications 46, 712-718.

KATES, J. (I970). Transcription of the vaccinia virus genome and the occurrence of polyriboadenylic acid sequences in messenger RNA. Cold Spring Harbor Symposia on Quantitative Biology 35, 743-752.

KERR, I. \& MARTIN, E. M. (1972). Simple method for the isolation of encephalomyocarditis virus ribonucleic acid. Journal of Virology 9, 559-56I.

LAI, M. M. C. \& DUESBerG, P. H. (I972). Adenylic acid-rich sequences in RNAs of Rous sarcoma virus and Rauscher mouse leukemia virus. Nature, London $235,383-386$.

LOWRY, O. H., ROSEBrough, N. J., FARR, A. L. \& RANDALl, R. J. (195I). Protein measurement with the Folin phenol reagent. Journal of Biological Chemistry 193, 265-275.

MARTIN, R. G. \& AMES, B. N. (I96I). A method for determining the sedimentation behavior of enzymes. Application to protein mixtures. Journal of Biological Chemistry 236, 1372-1379.

MENDECKI, J., LEE, S. Y. \& BRAWERMAN, G. (I972). Characteristics of the polyadenylic acid segment associated with messenger ribo-nucleic acid in mouse sarcoma 180 ascites cells. Biochemistry $\mathbf{1 1}, 792-797$.

PLAGEMANN, P. G. W. (I968). Mengovirus replication in Novikoff rat hepatoma and mouse L cells: Effects on the synthesis of host-cell macromolecules and virus-specific synthesis of ribonucleic acid. Journal of Virology 2, 461-473.

PlagemanN, P. G. W. (I970). Temperature- and phenol-induced alterations in sedimentation rates of 29-S and I8-S ribosomal RNA's from Novikoff hepatoma cells. Biochimica et biophysica acta 224, 45I-457.

PLAGEMANN, P. G. W. (I972). Nucleotide pools in Novikoff rat hepatoma cells growing in suspension culture. III. Effects of nucleosides in medium on levels of nucleotides in separate nucleotide pools for nuclear and cytoplasmic RNA synthesis. Journal of Cell Biology 52, I 31-146.

PLAGEMANN, P. G. W. \& SWIM, H. E. (1966). Replication of mengovirus. I. Effect on synthesis of macromolecules by host cell. Journal of Bacteriology 91, 2317-2326.

PLAGEMANN, P. G. W. \& SWIM, H. E. (1968). Synthesis of ribonucleic acid by mengovirus-induced RNA polymerase in vitro: nature of products and of RNase-resistant intermediate. Journal of Molecular Biology 35, I3-35.

SPIRIN, A. S. (I963). Some problems concerning the macromolecular structure of ribonucleic acids. Progress in Nucleic Acid Research 1, 30r-345.

(Received 2 I June 1972) 